\title{
IN VITRO HEMOLYTIC ACTIVITY OF Bothrops lanceolatus (FER-DE-LANCE) VENOM
}

\section{Martins LJ (1), de Araújo PMF (2), Bon C (3) ${ }^{\dagger}$, Hyslop S (1), de Araújo AL (1)}

(1) Department of Pharmacology, School of Medical Sciences, State University of Campinas, Unicamp, Campinas, São Paulo State, Brazil; (2) Department of Microbiology and Immunobiology, Institute of Biology, State University of Campinas, Unicamp, Campinas, São Paulo State, Brazil; (3) National Museum of Natural History, Paris, France.

ABSTRACT: Bothrops lanceolatus venom contains a variety of enzymatic and biological activities. The present work investigated the hemolytic activity of this venom and its phospholipase $A_{2}\left(P L A_{2}\right)$. Bothrops lanceolatus venom $(6.7 \mu \mathrm{g} / \mathrm{mL})$ caused indirect hemolysis of cow, horse, rat and sheep erythrocytes, with horse erythrocytes being the most sensitive; no direct hemolysis was observed. Hemolysis in sheep erythrocytes was concentration-dependent $(5-11.7 \mu \mathrm{g} / \mathrm{mL})$ and markedly attenuated by heating the venom for 30 minutes at $\geq 40^{\circ} \mathrm{C}$ and by the $\mathrm{PLA}_{2}$ inhibitor $p$-bromophenacyl bromide. An acidic PLA $2(5 \mu \mathrm{g} / \mathrm{mL})$ purified from $B$. lanceolatus venom also caused hemolysis. This $\mathrm{PLA}_{2}$ showed immunoprecipitin lines with antivenom against $B$. lanceolatus, which suggests that the enzymatic and hemolytic activities of this enzyme may be neutralized during antivenom therapy. These results indicate that $B$. lanceolatus venom and its $\mathrm{PLA}_{2}$ can cause hemolysis in vitro.

KEY WORDS: Bothrops lanceolatus, hemolytic activity, phospholipase $A_{2}$, snake venom.

CONFLICTS OF INTEREST: There is no conflict.

FINANCIAL SOURCE: CNPq.

\section{CORRESPONDENCE TO:}

ALBETIZA LÔBO DE ARAÚJO, Departamento de Farmacologia, Faculdade de Ciências Médicas, Universidade Estadual de Campinas, UNICAMP, Caixa Postal 6111, Campinas, SP, 13.083-970, Brasil. Phone: +55 193521 9529. Fax: +55 19 3289 2968. Email: albetiza@fcm.unicamp.br. 


\section{INTRODUCTION}

Bothrops lanceolatus is endemic to the Caribbean island of Martinique (1). Envenomation by this species produces local (edema, pain, hemorrhage, necrosis) and systemic (coagulopathy) effects, with coagulation disturbances (thrombosis) being the most important cause of clinical complications and mortality (2-4). Enzymes that may contribute to these effects include an esterase (5), a caseinolytic protease (6), a hemorrhagic metalloproteinase (7) and an acidic phospholipase (8). The hemolytic activity of $B$. lanceolatus venom and involvement of $\mathrm{PLA}_{2}$ in this phenomenon have not been extensively studied, although Bogarín et al. (9) reported that the hemolytic activity of $B$. lanceolatus venom was neutralized by homologous antivenom. In this report, we describe some characteristics of the hemolysis caused by $B$. lanceolatus venom in vitro.

\section{MATERIALS AND METHODS}

\section{Venom, PLA 2 and Antivenom}

Bothrops lanceolatus venom was supplied by the Unité des Venins, Institut Pasteur (Paris, France) and was stored at $-20^{\circ} \mathrm{C}$ until use. Acidic $\mathrm{PLA}_{2}$ (fraction $\mathrm{F}_{3} 2$ ) was purified from $B$. lanceolatus venom by a combination of gel filtration and ionexchange chromatography, as previously described (8). Antivenom (batch BO 278, Pasteur Institute, Paris) produced in horses immunized with $B$. lanceolatus venom was stored in lyophilized form.

\section{Assay for Hemolytic Activity}

Sheep blood was obtained from a commercial sheep breeder (Biotério Boa Vista, Fazenda São Sebastião, Patrocínio Paulista, SP, Brazil), cow and horse blood were obtained from a commercial slaughterhouse, and blood from Wistar rats was collected from animals provided by the university's Multidisciplinary Center for Biological Investigation (CEMIB/UNICAMP). Suspensions of washed erythrocytes were prepared in phosphate-buffered saline (PBS) using standard procedures whereas the indirect hemolytic activity was assayed in a mixture containing venom or $\mathrm{PLA}_{2}$, hen egg-yolk lecithin and erythrocytes, essentially as described by Gutiérrez et al. (10). The relationship between venom concentration and hemolysis was investigated in sheep erythrocytes. Direct hemolytic activity was assessed in incubations without egg-yolk lecithin. Hemolytic activity was expressed as a 
percentage of the total hemolysis (100\%) obtained by lysing erythrocytes in distilled water.

\section{Heat Stability of the Hemolytic Activity}

The heat stability of the hemolytic activity was determined by incubating venom at 25 , $40,50,70$ and $90^{\circ} \mathrm{C}$ for 30 minutes followed by cooling and then assaying the residual hemolytic activity in sheep erythrocytes.

\section{Role of PLA 2 in the Hemolytic Activity}

The role of $\mathrm{PLA}_{2}$ in the hemolytic activity of the venom was assessed by incubating venom with $2.88 \mathrm{mM}$ p-bromophenacyl bromide (pBPB) (Sigma Chemical Co., USA) for 30 minutes at $37^{\circ} \mathrm{C}$, after which the residual $\mathrm{PLA}_{2}$ and hemolytic activities were assayed in 96-well plates, as described by Nishida et al. (11). Each well contained $200 \mu \mathrm{L}$ of hen egg-yolk emulsion as substrate in PBS containing $2 \mathrm{mM} \mathrm{CaCl}_{2}$ and 40 $\mu \mathrm{L}$ of venom. The increase in absorbance at $750 \mathrm{~nm}$ was recorded for up to 40 minutes in a SpectraMax 340® multiwell plate reader (Molecular Devices, USA) and the activity was expressed as the increase in absorbance at $750 \mathrm{~nm} /$ minute. Hemolytic activity was assayed as described above, using sheep erythrocytes. All assays were run in duplicate and corrected for appropriate blanks.

\section{Immunological Analysis}

Immunodiffusion of the venom and purified PLA $\mathrm{P}_{2}$ was done in PBS in $1 \%$ agar gels, as described by Ouchterlony (12), using a $10 \%(\mathrm{w} / \mathrm{v})$ solution of $B$. lanceolatus antivenom. After incubation in a humidified chamber for 48 hours at room temperature, the slides were washed extensively in $0.9 \%(\mathrm{w} / \mathrm{v}) \mathrm{NaCl}$ and the immunoprecipitin bands were detected by Coomassie blue staining.

Immunoelectrophoresis was done in $1 \%$ agar gels poured on glass slides. Samples of venom and purified $\mathrm{PLA}_{2}$ were applied to the gels and run for one hour at $6 \mathrm{~V} / \mathrm{cm}$ in $50 \mathrm{mM}$ veronal buffer, $\mathrm{pH} 8.4$ (13). Following electrophoresis, a 10\% (w/v) solution of $B$. lanceolatus antivenom was placed in the central trough and the slides were incubated for 48 hours at room temperature in a humidified chamber. After extensive washing in $0.9 \%(\mathrm{w} / \mathrm{v}) \mathrm{NaCl}$, the gels were dried and stained with Coomassie blue. 


\section{Statistical Analysis}

The results were expressed as the mean \pm S.E.M., and statistical comparisons $(p<$ 0.05 ) were done using Student's $t$-test or analysis of variance (ANOVA) followed by the Tukey test.

\section{RESULTS}

\section{Hemolytic Activity of $B$. lanceolatus Venom and Purified PLA 2}

Figure $1 \mathrm{~A}$ shows that $B$. lanceolatus venom caused indirect hemolysis of erythrocytes in all of the species examined, with horse erythrocytes being the most susceptible and sheep erythrocytes the least susceptible $(p<0.05)$; there was no significant difference between the degree of hemolysis of rat and cow erythrocytes $(p$ $>$ 0.05). No direct hemolysis was observed with any of these species (data not shown; $n=4$ ). In subsequent experiments, sheep erythrocytes were used because these were readily obtained from an established laboratory.

Bothrops lanceolatus venom caused concentration-dependent hemolysis of sheep erythrocytes that was maximal at $>10 \mu \mathrm{g} / \mathrm{mL}$ (Figure 1B). This hemolytic activity was markedly attenuated by heating the venom for 30 minutes at $\geq 40^{\circ} \mathrm{C}$, with complete inhibition of hemolytic activity occurring at $\geq 50^{\circ} \mathrm{C}$ (Figure $1 \mathrm{C}$ ). Incubation with $p B P B$ significantly $(p<0.05)$ inhibited the $\mathrm{PLA}_{2}$ activity of the venom (from 74.0 $\mathrm{A}_{750 \mathrm{~nm}} /$ minute to $3.7 \mathrm{~A}_{750 \mathrm{~nm}} /$ minute) and completely abolished the hemolytic activity ( $\mathrm{n}$ = 4). Purified $\mathrm{PLA}_{2}(5 \mu \mathrm{g} / \mathrm{mL})$ caused total hemolysis of sheep erythrocytes (a complete concentration-response curve of this hemolytic activity was not obtained because of the limited amount of pure $\mathrm{PLA}_{2}$ available) (Figure 1D). 

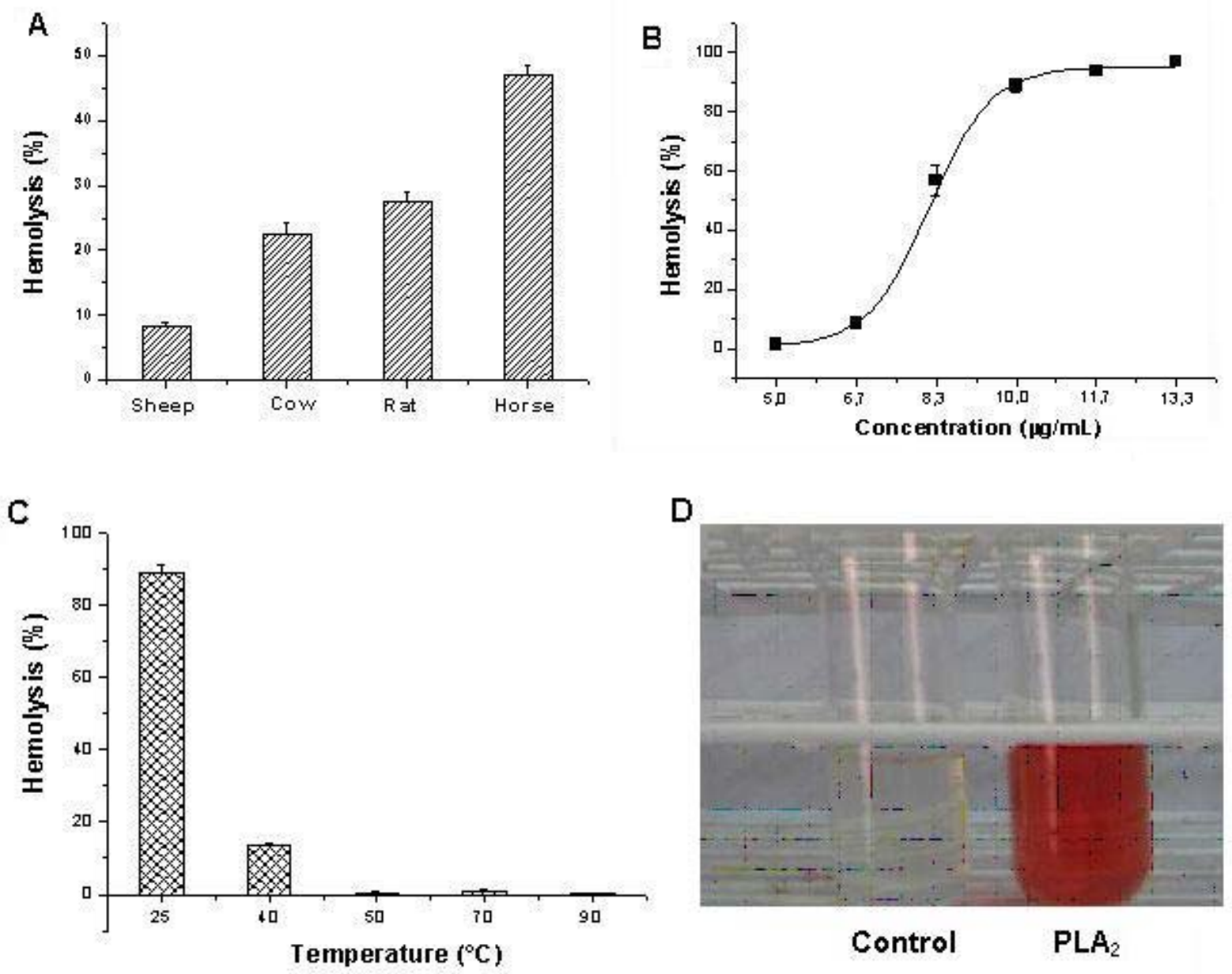

Figure 1. Hemolytic activity of $B$. lanceolatus venom $(6.7 \mu \mathrm{g} / \mathrm{mL})$ and its purified $\mathrm{PLA}_{2}$. (A) Indirect hemolysis of erythrocytes from various species. (B) Concentrationdependent hemolysis of sheep erythrocytes by $B$. lanceolatus venom. (C) Thermolability of the hemolytic activity of $B$. lanceolatus venom $(10 \mu \mathrm{g} / \mathrm{mL})$ in sheep erythrocytes. (D) Hemolysis of sheep erythrocytes by purified $\operatorname{PLA}_{2}(5 \mu \mathrm{g} / \mathrm{mL})$. The control tube on the left shows no hemolysis. In panels $\mathbf{A}$ to $\mathbf{C}$, hemolysis was expressed as a percentage of the total hemolysis (100\%) obtained by lysing erythrocytes in distilled water (mean \pm SEM, $n=4$ independent experiments).

\section{Immunological Studies}

Figure 2 shows the immunoprecipitin lines obtained with $B$. lanceolatus venom and purified $\mathrm{PLA}_{2}$ after incubation with antivenom. Multiple lines were obtained with the venom but only one major line was seen with $\mathrm{PLA}_{2}$ in immunodiffusion and immunoelectrophoresis. 


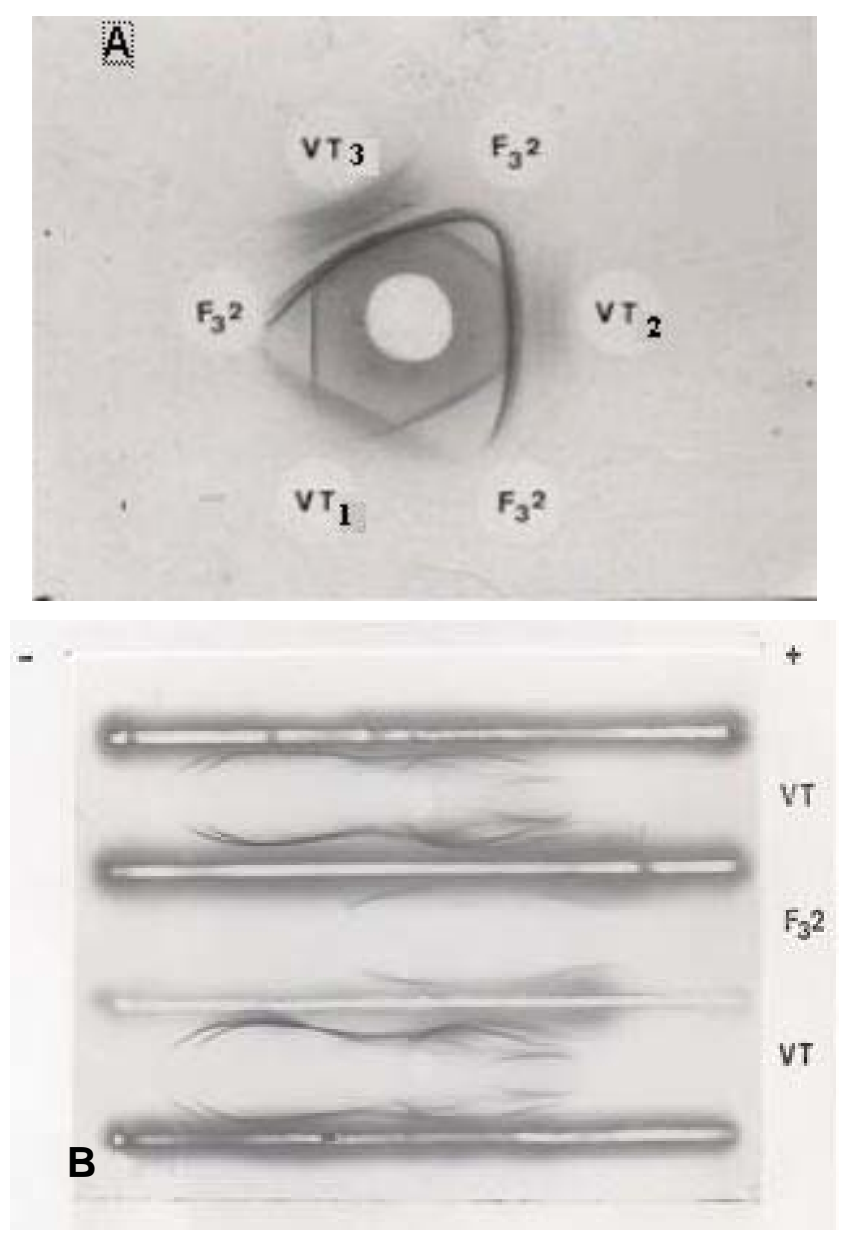

Figure 2. Immunoreactivity of $B$. lanceolatus venom $(\mathrm{VT})$ and purified $\mathrm{PLA}_{2}\left(\mathrm{~F}_{3} 2\right)$ with B. lanceolatus antivenom in (A) immunodiffusion and (B) immunoelectrophoresis. (A) The antigen concentrations were $0.1,0.5$ and $1.0 \mathrm{mg} / \mathrm{mL}\left(\mathrm{VT}_{1}, \mathrm{VT}_{2}\right.$ and $\left.\mathrm{VT}_{3}\right)$. (B) The antigen concentration was $2 \mathrm{mg} / \mathrm{mL}$.

$(-)$ and (+): negative and positive poles, respectively.

\section{DISCUSSION}

The results of this study indicate that $B$. lanceolatus venom can cause indirect hemolysis of erythrocytes from a variety of mammalian species. This action on erythrocytes was indirect since there was no hemolysis in the absence of egg-yolk lecithin. The hemolytic activity was concentration-dependent and thermolabile since heating the venom at $\geq 40^{\circ} \mathrm{C}$ resulted in little or no hemolysis. These findings generally agree with reports on the hemolytic activity of other Bothrops venoms (1416). Variation in species sensitivity to hemolysis as seen herein (sheep < cow/rat < horse) has also been observed with other Bothrops venoms, e.g., B. asper venom 
causes direct hemolysis of mouse erythrocytes but has no effect on goat, horse, rabbit, sheep and toad erythrocytes; in contrast, lysis of human erythrocytes requires bovine serum albumin and $\mathrm{Ca}^{2+}(17)$. These variations may reflect differences in the phospholipid composition of the erythrocyte plasma membrane of these species (1820 ), as well as the accessibility of the cellular membrane targets such as negative phospholipids to $\mathrm{PLA}_{2}$ action $(17,18)$. Incubation of the venom at different temperatures indicated that the venom component responsible for hemolysis is thermolabile. Other biological activities of $B$. lanceolatus, such as rat paw edema, leukocyte migration and hemorrhagic activity, are also thermolabile $(7,21,22)$.

A role for venom $\mathrm{PLA}_{2}$ in the hemolytic activity was suggested by the finding that the loss of hemolysis paralleled the inhibition of $\mathrm{PLA}_{2}$ activity by $p B P B$. In addition, purified $\mathrm{PLA}_{2}$ also caused hemolysis. In agreement with this, various studies have shown that $\mathrm{PLA}_{2} \mathrm{~S}$ are the principal component of Bothrops venoms responsible for hemolysis (23-26). In addition to the hemolytic activity described herein, the $\mathrm{PLA}_{2}$ of $B$. lanceolatus venom also contributes to neutrophil migration during inflammation caused by this venom (21) and may be involved in the anticoagulant action of the venom (27).

The immunoprecipitin lines observed with purified $\mathrm{PLA}_{2}$ and $B$. lanceolatus antivenom in immunodiffusion and immunoelectrophoresis indicated that this protein was antigenic and was recognized by the antivenom. This finding supports the results of Bogarín et al. (9), who showed that this antivenom neutralized the indirect hemolytic activity of $B$. lanceolatus venom. Other studies have also shown that bothropic antivenoms can neutralize the $\mathrm{PLA}_{2}$ and hemolytic activities of homologous and heterologous Bothrops venoms (16, 28-32).

Although intravascular hemolysis has been observed following envenomation by Bothrops species (33), this phenomenon has not been documented after bites by $B$. lanceolatus, the main effects of which are edema, pain and coagulation disturbances (2-4). Hence, the clinical relevance of the findings described herein remains to be determined.

In conclusion, B. lanceolatus venom causes concentration-dependent hemolysis in vitro, with the order of susceptibility among erythrocytes from different species being sheep < cow/rat < horse. This activity is thermolabile and is apparently mediated by the PLA $\mathrm{P}_{2}$ of the venom. The cross-reactivity of the venom and PLA $\mathrm{A}_{2}$ with antivenom suggests that the hemolytic activity may be neutralized by antivenom. 


\section{ACKNOWLEDGMENTS}

The authors thank José Ilton dos Santos, Alessandra Priscila Ponciano, Célia A. A. C. Garcia and José Raimundo R. dos Reis for technical assistance, Marcelo Carvalho, Paulo A. F. Nunes and Paula L. Dotto for help with some of the experiments, and Silvia P. Irazusta for helpful comments on the manuscript. S.H. is supported by a research fellowship from CNPq.

\section{REFERENCES}

1. Campbell JA, Lamar WW. The venomous reptiles of the Western Hemisphere. Ithaca: Comstock Publishing Associates/Cornell University Press; 2004. 870 p.

2. Thomas L, Chausson N, Uzan J, Kaidomar S, Vignes R, Plumelle Y, Bucher B, Smadja D. Thrombotic stroke following snake bites by the "fer-de-lance" Bothrops lanceolatus in Martinique despite antivenom treatment: a report of three recent cases. Toxicon. 2006;48(1):23-8.

3. Thomas L, Tyburn B, Bucher B, Pecout F, Ketterle J, Rieux D, Smadja D, Garnier D, Plumelle Y, Research Group on Snake Bites in Martinique. Prevention of thromboses in human patients with Bothrops lanceolatus envenoming in Martinique: failure of anticoagulants and efficacy of a monospecific antivenom. Am J Trop Med Hyg. 1995;52(5):419-26.

4. Thomas L, Tyburn B, Research Group on Snake Bites in Martinique. Bothrops lanceolatus bites in Martinique: clinical aspects and treatment. In: Bon C, Goyffon M, editors. Envenomings and their treatments. Lyon: Fondation Marcel Mérieux; 1996. p. 255-65.

5. Lôbo de Araújo A, Donato JL, Bon C. Purification from Bothrops lanceolatus (fer de lance) venom of a fibrino(geno)lytic enzyme with esterolytic activity. Toxicon. 1998;36(5):745-58.

6. Lôbo de Araújo A, Donato JL, Leite GB, Prado-Franceschi J, Fontana MD, Bon C, Rodrigues-Simioni L. Neuromuscular action of Bothrops lanceolatus (fer de lance) venom and a caseinolytic fraction. Toxicon. 2002;40(9):1283-9.

7. Stroka A, Donato JL, Bon C, Hyslop S, Lôbo de Araújo A. Purification and characterization of a hemorrhagic metalloproteinase from Bothrops lanceolatus (fer de lance) snake venom. Toxicon. 2005;45(4):411-20. 
8. Lôbo de Araújo A, Radvanyi F, Bon C. Purification of acidic phospholipase $A_{2}$ from Bothrops lanceolatus (fer de lance) venom: molecular and enzymatic properties. Toxicon. 1994;32(9):1069-81.

9. Bogarín G, Romero M, Rojas G, Lutsch C, Casadamont M, Lang J, Otero R, Gutiérrez JM. Neutralization, by a monospecific Bothrops lanceolatus antivenom, of toxic activities induced by homologous and heterologous Bothrops snake venoms. Toxicon. 1999;37(3):551-7.

10. Gutiérrez JM, Ownby CL, Odell GV. Pathogenesis of myonecrosis induced by crude venom and a myotoxin of Bothrops asper. Exp Mol Pathol. 1984;40(3):367-79.

11. Nishida S, Terashima M, Shimazu T, Takasaki $C$, Tamiya N. Isolation and properties of two phospholipases $A_{2}$ from the venom of an Australian elapid snake (Pseudechis australis). Toxicon. 1985;23(1):73-85.

12. Ouchterlony O. Immunodiffusion and immunoelectrophoresis. In: Wier BM, editor. Handbook of experimental immunology. Oxford: Blackwell Scientific; 1967. p. 665705.

13. Grabar P, Burtin P. Immuno-electrophoretic analysis. Amsterdam: Elsevier Publishing Co.; 1964. 357 p.

14. Martínez Cadillo E, Bonilla Ferreyra C, Zavaleta A. Actividad hemolítica de venenos de serpientes de los géneros Bothrops, Lachesis, Crotalus y Micrurus (Serpentes: Viperidae y Elapidae). Rev Biol Trop. 1991;39(2):311-4.

15. Otero R, Osorio RG, Valderrama R, Giraldo CA. Efectos farmacológicos y enzimáticos de los venenos de serpientes de Antioquia y Chocó (Colombia). Toxicon. 1992;30(5-6):611-20.

16. Rojas G, Gutiérrez JM, Gené JA, Gómez M, Cerdas L. Neutralization of toxic and enzyme activities of four venoms from snakes of Guatemala and Honduras by the polyvalent antivenin produced in Costa Rica. Rev Biol Trop. 1987;35(1):59-67.

17. Quirós S, Gené JA, Gutiérrez JM, Thelestam M. Effect of Bothrops asper (fer de lance) snake venom on erythrocyte membrane. A comparative study. Comp Biochem Physiol C. 1992;101(2):433-6.

18. Díaz C, León G, Rucavado A, Rojas N, Schroit AJ, Gutiérrez JM. Modulation of the susceptibility of human erythrocytes to snake venom myotoxic phospholipases $\mathrm{A}_{2}$ : role of negatively charged phospholipids as potential membrane binding sites. Arch Biochem Biophys. 2001;391(1):56-64. 
19. Rosenberg P. Pharmacology of phospholipase $A_{2}$ from snake venoms. In: Lee CY, editor. Snake venoms. Handbook of experimental pharmacology. Berlin: Springer; 1979. p. 403-47. vol. 52.

20. Rosenberg P. Phospholipases. In: Shier WT, Mebs D, editors. Handbook of toxinology. New York: Marcel Dekker; 1990. p. 67-277.

21. Arruda VA, de Queiroz Guimarães A, Hyslop S, de Araújo PM, Bon C, Lôbo de Araújo A. Bothops lanceolatus (fer de lance) venom stimulates leukocyte migration into the peritoneal cavity of mice. Toxicon. 2003;41(1):99-107.

22. de Faria L, Antunes E, Bon C, Lôbo de Araújo A. Pharmacological characterization of the rat paw edema induced by Bothrops lanceolatus (fer de lance) venom. Toxicon. 2001;39(6):825-30.

23. Ketelhut DFJ, Homem de Mello M, Veronese ELG, Esmeraldino LE, Murakami MT, Arni RK, Giglio JR, Cintra ACO, Sampaio SV. Isolation, characterization and biological activity of acidic phospholipase $A_{2}$ isoforms from Bothrops jararacussu snake venom. Biochimie. 2003;85(10):983-91.

24. Lomonte B, Angulo Y, Calderón L. An overview of lysine-49 phospholipase $A_{2}$ myotoxins from crotalid snake venoms and their structural determinants of myotoxic action. Toxicon. 2003;42(8):885-901.

25. Soares AM, Andrião-Escarso SH, Bortoleto RK, Rodrigues-Simioni L, Arni RK, Ward RJ, Gutiérrez JM, Giglio JR. Dissociation of enzymatic and pharmacological properties of piratoxins-I and -III, two myotoxic phospholipases $A_{2}$ from Bothrops pirajai snake venom. Arch Biochem Biophys. 2001;387(2):188-96.

26. Soares AM, Giglio JR. Chemical modifications of phospholipases $A_{2}$ from snake venoms: effects on catalytic and pharmacological properties. Toxicon. 2003;42(8):855-68.

27. Lôbo de Araújo A, Kamiguti A, Bon C. Coagulant and anticoagulant activities of Bothrops lanceolatus (Fer de lance) venom. Toxicon. 2001;39(2-3):371-5.

28. Bogarín G, Segura E, Durán G, Lomonte B, Rojas G, Gutiérrez JM. Evaluación de la capacidad de cuatro antivenenos comerciales para neutralizar el veneno de la serpiente Bothrops asper (terciopelo) de Costa Rica. Toxicon. 1995;33(9):1242-7.

29. Gutiérrez JM, Ávila C, Rojas E, Cerdas L. An alternative in vitro method for testing the potency of the polyvalent antivenom produced in Costa Rica. Toxicon. 1988;26(4):411-3. 
30. Maria WS, Cambuy MO, Costa JO, Velarde DT, Chávez-Olórtegui C. Neutralizing potency of horse antibothropic antivenom. Correlation between in vivo and in vitro methods. Toxicon. 1998;36(10):1433-9.

31. Muniz EG, Maria WS, Estevão-Costa MI, Buhrnheim P, Chávez-Olórtegui C. Neutralizing potency of horse antibothropic Brazilian antivenom against Bothrops snake venoms from the Amazonian rain forest. Toxicon. 2000;38(12):1859-63.

32. Otero R, Nuñez V, Osorio RG, Gutiérrez JM, Giraldo CA, Posada LE. Ability of six Latin American antivenoms to neutralize the venom of mapana equis (Bothrops atrox) from Antioquia and Chocó (Colombia). Toxicon. 1995:33(6):809-15.

33. França FOS, Málaque CMS. Acidente botrópico. In: Cardoso JLC, França FOS, Wen FH, Málaque CMS, Haddad Jr. V, editors. Animais peçonhentos no Brasil: biologia, clínica e terapêutica dos acidentes. São Paulo: Sarvier/FAPESP; 2003. p. 72-86. 